\title{
Identification of Planktonic Genera/Species and Determination of the Physicochemical Factors Favoring the Growth of These Species in Cape 7 (Aftissat) Zone, South of Morocco
}

\author{
Bouchra Bouhaddioui, Aziza Hal Aberrhaman, Lalla Aicha Lrhorfi, Rachid Bengueddour \\ Biology Department, Laboratory Biochemistry, Biotechnology, Health and Environment, Faculty of Science, Ibn Tofail University, \\ Kenitra, Morocco \\ Email:dr_bouchra2010@yahoo.fr,azza-20111@hotmail.fr, alrhorfi_com@yahoo.fr,rachidbengueddour@yahoo.fr
}

How to cite this paper: Bouhaddioui, B., Hal Aberrhaman, A., Lrhorfi, L.A. and Bengueddour, R. (2020) Identification of Planktonic Genera/Species and Determination of the Physicochemical Factors Favoring the Growth of These Species in Cape 7 (Aftissat) Zone, South of Morocco. Open Journal of Ecology, 10, 77-87. https://doi.org/10.4236/oje.2020.102006

Received: December 31, 2019

Accepted: February 25, 2020

Published: February 28, 2020

Copyright ( 2020 by author(s) and Scientific Research Publishing Inc. This work is licensed under the Creative Commons Attribution International License (CC BY 4.0).

http://creativecommons.org/licenses/by/4.0/ (c) (i) Open Access

\begin{abstract}
The diversity of oceanic phytoplankton communities depends in part on environmental, physical, chemical and biological factors where they are. The study that we conducted in cape 7 (Aftissat) zone, south of Morocco, located $232 \mathrm{~km}$ south of Laayoune city and $62 \mathrm{~km}$ south of Boujdour city, aims at the identification of planktonic genera/species and determination of the physicochemical factors favoring the growth of these species. The study was carried out on 427 samples, distributed, therefore, as follows, $57.2 \%(\mathrm{n}=245)$ of the samples during the year 2016 and $42.5 \%(\mathrm{n}=182)$ in the year 2017. In addition, $32.8 \%$ and $27.6 \%$ of the samples were taken, respectively, in winter and autumn, $24.4 \%$ of the samples in summer and $15.2 \%$ of all samples taken in the spring. We have identified 30 phytoplankton species, of which $70 \%$ ( $\mathrm{n}=$ 21 ) are diatoms, $26.67 \%$ are dinoflagellates and one species is silicoflagellates. Moreover, the most abundant species in the diatoms are Navicula sp. (69), Licmophora (47), Nitzschia sp. (35), Pseudo nitzschia spp. (31) and in the class Dinoflagellates, Scrippsiella spp. (24), Protoperidinium spp. (11). The physicochemical parameters show very significant associations with density, so they favor a very high abundance species, especially those belonging to the diatom class. Some toxic species have also been identified, but with very low frequencies, below the norm. The cape d'Afissat has a very important role in the economic life of the region, so we must increase efforts to preserve it and if it is possible to improve the quality of water.
\end{abstract}

\section{Keywords}

Phytoplankton, Cape 7 (Aftissat), Physicochemical Parameters, 


\section{Introduction}

$98 \%$ of the surface waters of the terrestrial globe are marine waters; the remaining $2 \%$ is continental waters represented by rivers, lakes and ponds. This vital food provides added economic value to many areas such as agriculture, energy production and industry [1] [2]. Numerous national and international studies have shown that disruption of aquatic ecosystems can lead to various phenomena such as eutrophication [3], proliferation of phytoplankton, anoxia, food poisoning [4] [5] [6]. Phytoplankton is all the unicellular microscopic algae that float in the water. They are able to proliferate intensively thus forming red, brown or green waters; these efflorescences can be sources of nuisance, reducing the transparency of the water and the concentration of dissolved oxygen, resulting in a loss of biodiversity of all trophic levels [7].

There are 84 listed wetlands in Morocco according to the 1997 Protected Areas Study. An ongoing study reports about 300 sites covering an area of 400,000 ha. The region of Laayoune-Boujdour-Sakia el Hamra is rich in wetlands such as cape of Afissat area.

The objective of this study is to determine the phytoplankton community and to assess the physicochemical quality of cape of Afissat.

\section{Material and Methods}

\subsection{Climatological Characteristics of the Study Area}

The area cape 7 (Aftissat), with the geographic coordinates $25^{\circ} 35^{\prime} 31.08^{\prime \prime} \mathrm{N}$ $14^{\circ} 41^{\prime} 16.82^{\prime \prime} \mathrm{O}$, is located $232 \mathrm{~km}$ south of the town of Laayoune and $62 \mathrm{~km}$ south of the city Boujdour. The geomorphology of the coastline is characterized by the dominance of the cliffs with a limited narrow range (Figure 1).

The climate is characterized during the summer by the dominance of the trade winds, which generate activity of the Upwelling's, which results in the enrichment of water in mineral matter. The surface temperature between $18.4^{\circ} \mathrm{C}$ north cape Boujdour and between $18.4^{\circ} \mathrm{C}$ and $21.6^{\circ} \mathrm{C}$ south cape Boujdour. In the deepest waters, outside the upwelling zone, the temperature reaches $20^{\circ} \mathrm{C}$ to $21.6^{\circ} \mathrm{C}$. Surface currents are induced by atmospheric circulation.

\subsection{Sampling Methods}

\subsubsection{Species Identification}

Samples are taken at high tide $( \pm 2 \mathrm{~h})$ at the surface, using one-liter spill bottle at one meter depth. The samples thus obtained are fixed on site. After vigorous stirring, the samples are decanted for 24 hours and then subjected to observation under optical microscope morpho-anatomic characters (shape, size and color) representing the identification keys retained by Gregoire et al., 1978, Bourrelly, 


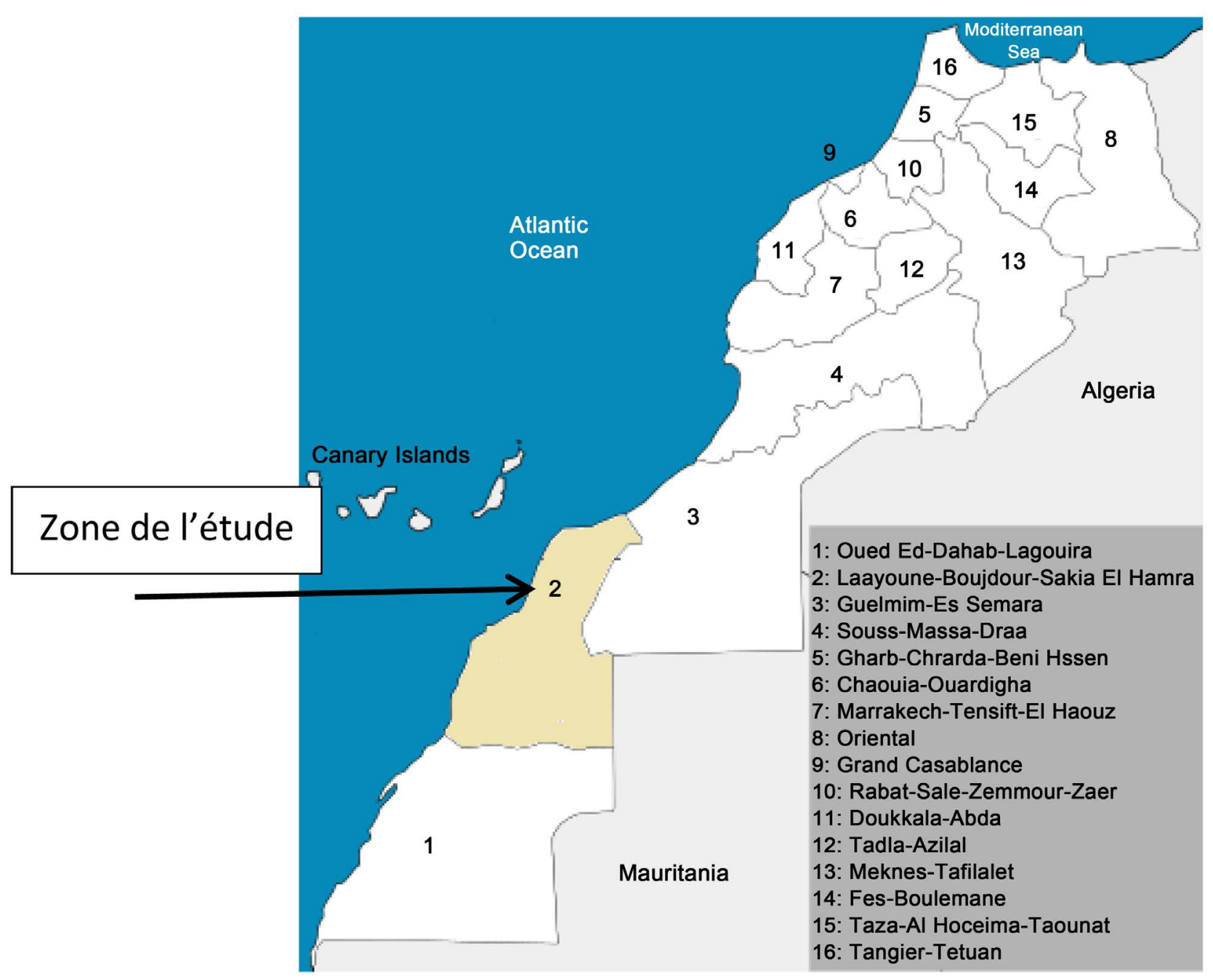

Figure 1. Map of morocco and study area.

1985 [8] [9]. The cells then are counted per liter per vat. With five repetitions and only the average values are taken into consideration.

\subsubsection{Measurement of Physicochemical Parameters}

The physical parameters (temperature, salinity and $\mathrm{pH}$ ) were measured in situ using a portable multi-parameter probe of WTW LF 197 brand (accuracy of 0.1 unit).

Dissolved oxygen was determined by Winkler's chemical method, sampling was carried out in special glass vials with ground glass stoppers of known volume. Oxygen is fixed on site by the addition of reagents. The method is designed to isolate the sample from air and fix dissolved oxygen as quickly as possible by reaction with a precipitate of manganese hydroxide formed in the sample. Thanks to a succession of reactions, we finally obtain an iodine solution, easily dosable with precision, of concentration proportional to that of the oxygen initially present. The results are expressed in $\mathrm{mg} / \mathrm{l}$ [10].

The samples intended for the analysis of the nitrite, nitrate and phosphate 
were taken in sub-surface to approximately $0.5 \mathrm{~m}$ of depth in polyethylene bottles, preserved protected from light at a temperature $\mathrm{d} "$ about $4^{\circ} \mathrm{C}$. They were dosed by colorimetry according to the protocols described by Aminot and Kerouel, 2004 [10].

\subsection{Statistical Analyzes}

The collected data are entered on an Excel support, the exploitation is carried out on a statistical processing software. The chosen analyzes in this sense are significance tests such as single-point analysis of variance, correlations, principal component analysis. The results are generally expressed as relative frequencies and/or means \pm standard deviation.

\section{Results}

\subsection{Description of Phytoplankton Samples from the Study Area}

The study we conducted in the area of the area cape 7 (Aftissat), is focused on 427 samples. They are distributed, therefore, as follows, $57.2 \%(n=245)$ of the levies in 2016 and $42.5 \%(n=182)$ in the year 2017. In addition, $32.8 \%$ and $27.6 \%$ of the samples were taken, respectively, in winter and autumn. $24.4 \%$ of the samples in summer. However, $15.2 \%$ of all samples were taken in the spring.

Of the total samples, 30 phytoplankton species were identified (Table 1), of which $70 \%(n=21)$ were diatoms, $26.67 \%$ were dinoflagellates and one species was silicoflagellates. Moreover, the most abundant species in the diatoms are

Table 1. Distribution of phytoplankton species identified in the study area according to the algal classes.

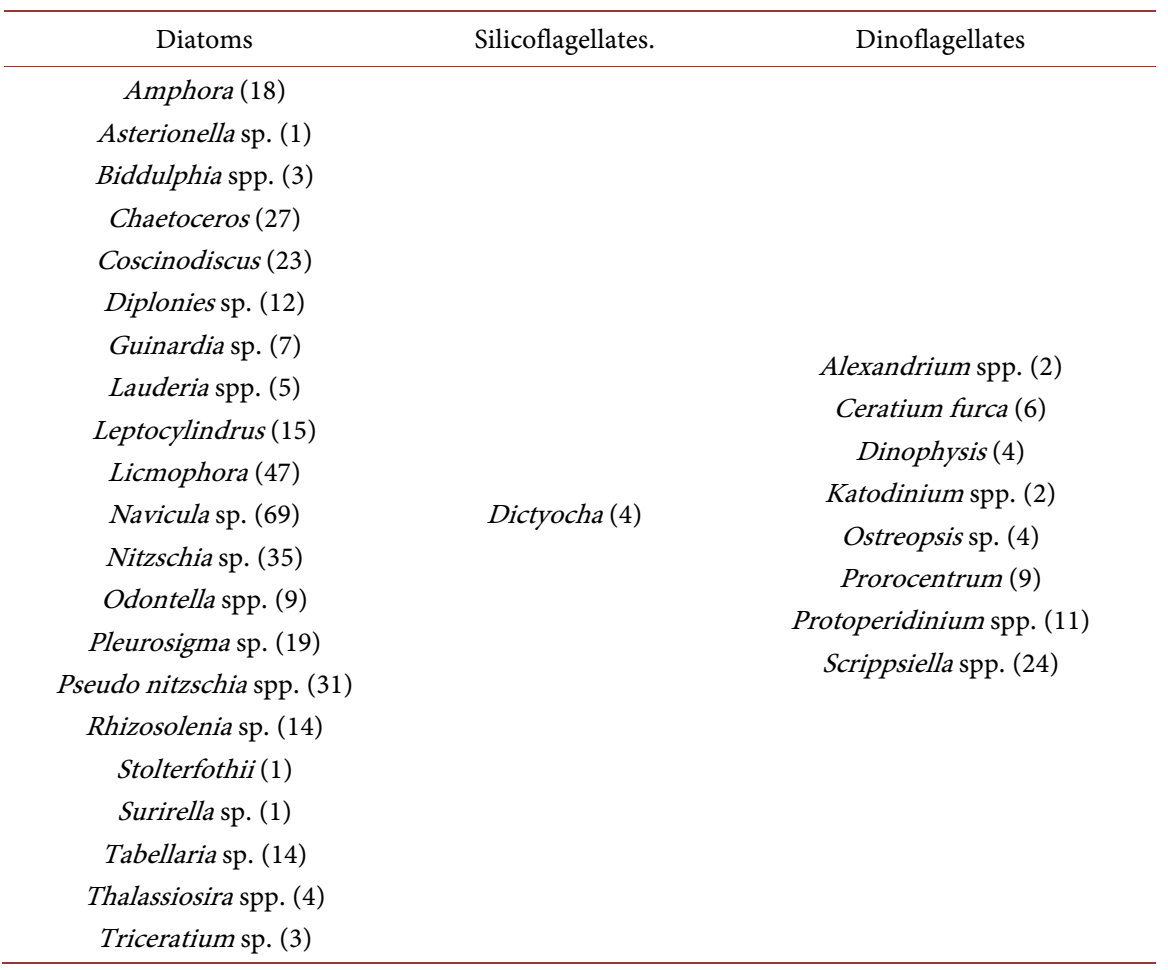


Navicula sp. (69), Licmophora (47), Nitzschia sp. (35), Pseudo nitzschia spp. (31) and in the class Dinoflagellates, Scrippsiella spp. (24), Protoperidinium spp. (11).

At the same time, three of the 30 species identified are classified as having high toxicity; these unicellular microalgae are Dinophysis (Dinoflagellates); Prorocentrum (Dinoflagellates) and Pseudo nitzschia spp. (Diatoms). These microorganisms produce phytotoxins most often causing food poisoning, without the need for the presence of the germ, this occurs during the algal bloom.

\subsection{Density of Species Identified in the Aftissat Zone}

The monthly and seasonal distribution of phytoplankton density during the two years of study shows that the average density is $366.34 \pm 19.22$, with a minimum average density of 40 and a maximum average density of 2280. Indeed, the analysis of variance with only one criterion of classification "effect month or season" shows a significant difference ("fisher $=2.62$ "; $\mathrm{p}<0.003$ ). Figure 2 shows the monthly and seasonal trends in average densities. This graph shows that the average maximum densities are recorded during the months of July and September, with respectively 518.182 and 516.4 and low in December (200). The grouping of monthly densities by season shows that the density is much higher in summer that is to say during the warm months and stable during the other seasons.

The distribution of the three algal classes listed in the sampling area shows by analysis of variance (Fisher $=14.61, \mathrm{p}<0.000$ ) that diatoms are the most frequent, with an average density of $407.87 \pm 21.72$ followed by dinoflagellates with an average density of $138.49 \pm 17.03$ and finally the sicicoflagellate class with a density of $70 \pm 10$. However, the distribution of species identified according to their density has allowed them to be classified into three groups:

- The first group is composed of species with the highest densities, such as Pseudo nitzschia spp. (744), Asterionella sp. (660), Navicula sp. (544.67) and Chaetoceros (500).

- The second group includes the less abundant species with a density below

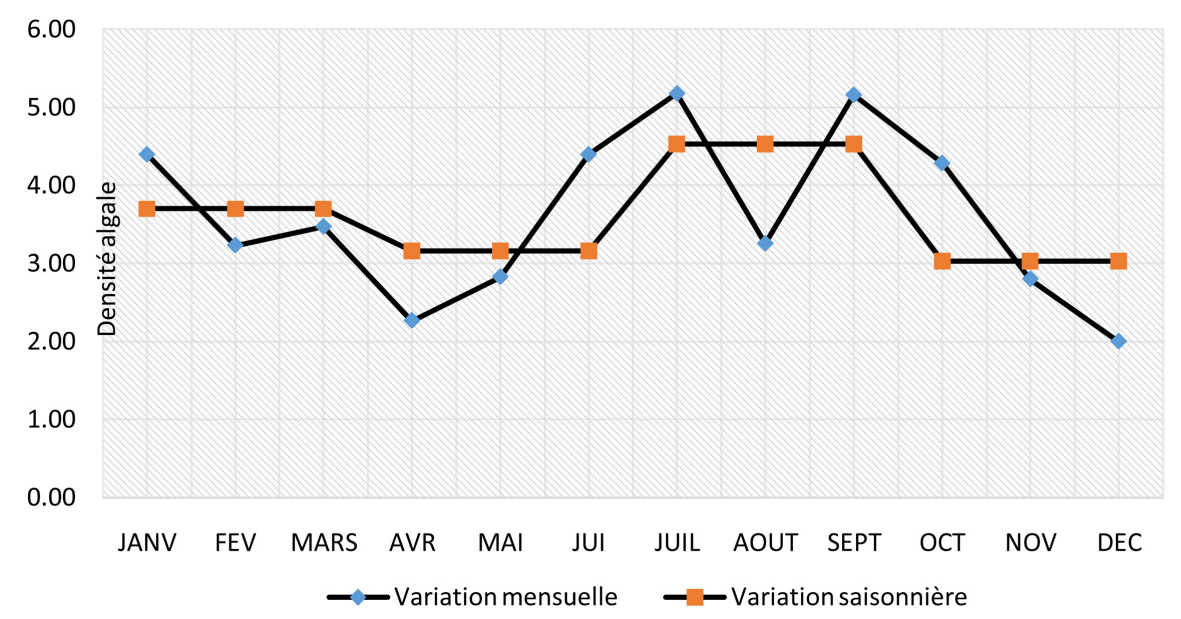

Figure 2. Monthly and seasonal evolution of phytoplankton the Aftissat zone. 
200 such as Biddulphia spp. (93.33), Triceratium sp. (93.33), Protoperidinium spp. (84), Dinophysis (80), Surirella sp. (80), Dictyocha (70).

- The third group is composed of other phytoplankton species with a density between 100 and 500 . This group is characterized by the presence of toxic species.

\subsection{Frequency of Occurrence of Phytoplankton Collected}

The distribution of phytoplankton species identified according to the frequency of occurrence shows that:

- The genus Navicula is encountered during the 12 months of the year of study (ubiquitous).

- The Chaetoceros genera; Licmophora; Pseudo nitzschia spp. are constant (encountered 11 months out of 12 and their frequency of appearance is 83.33\%).

- The genera, Amphora and Scrippsiella spp. are regular; they are present 10 months at the time of sampling, with a frequency of appearance of $66.66 \%$.

- Rare types encountered one to two months out of 12 and their frequency of appearance less than 25\% which are: Alexandrium spp.; Asterionella sp.; Dictyocha; Katodinium spp.; Stolterfothii and Surirella sp.

\subsection{Physicochemical Analyzes in the Study Area}

\subsubsection{Temperature}

The monthly temperature distribution recorded in the surface waters of the Aftissat site during the two years of study shows that the average annual temperature is $19.48^{\circ} \mathrm{C}$, with averages exceeding $20^{\circ} \mathrm{C}$ in August $\left(21.60^{\circ} \mathrm{C}\right)$, September $\left(20.90^{\circ} \mathrm{C}\right)$ and October $\left(21.39^{\circ} \mathrm{C}\right)$ and averages less than $18^{\circ} \mathrm{C}$ recorded in February $\left(17.62^{\circ} \mathrm{C}\right)$ and March $\left(17.01^{\circ} \mathrm{C}\right)$. In fact, the mean temperature ranges recorded during the samplings carried out are in diatoms and dinoflagellates, respectively, of [19.32 - 19.66] and [19.15 - 20.05], whereas in the sillicoflagellates, it is of [17.46 - 18.16]. However, species identified at mean temperatures exceeding $20^{\circ} \mathrm{C}$ at the time of sampling are Biddulphia spp., Diplomas sp., Ceratium furca and Thalassiosira spp. On the other hand, the species that are recorded during sampling at temperatures below $19^{\circ} \mathrm{C}$ are as follows Alexandrium spp., Katodinium spp.; Leptocylindrus, Odontella spp., Asterionella sp.; Lauderia spp.; Stolterfothii; Dictyocha and Ostreopsis sp. While other species have identified themselves at temperatures between $19^{\circ} \mathrm{C}$ and $20^{\circ} \mathrm{C}$.

So we can say that the temperature is strongly correlated with plankton abundance in the Aftissat zone.

\subsection{2. $\mathrm{pH}$}

The average $\mathrm{pH}$ distribution over months shows that the average annual $\mathrm{pH}$ is $7.74 \pm 0.14$, with a minimum $\mathrm{pH}$ of 7.51 and a maximum $\mathrm{pH}$ of 8.10 . The Fisher test shows a very highly significant month effect on the $\mathrm{pH}$ distribution (Fisher $=$ 
94.25, $\mathrm{p}<0.000)$. Moreover, the comparison of the average shows that the $\mathrm{pH}$ is minimal in March $(\mathrm{pH}=7.51)$ and maximum in September $(\mathrm{pH}=7.9)$, the $\mathrm{pH}$ during the other months fluctuates between these two extreme values.

Nevertheless, during the samples taken, the average $\mathrm{pH}$ recorded in the three algal classes did not show any significant differences (Fisher $=1.15, \mathrm{p}<0.32$ ). However, species identified at mean $\mathrm{pHs}$ less than 7.7 at the time of sampling are Katodinium spp. (7.585); Ostreopsis sp. (7.61); Lauderia spp. (7.64); Biddulphia sp. (7.67) and Ceratium furca (7.70). However, the species recorded, during sampling; under very high $\mathrm{pH}$ conditions $(\mathrm{pH}>7.8)$ are Leptocylindrus (7.786); Triceratium sp. (7.81); Dictyocha (7.83) and Thalassiosira spp. (7.8725).

A significant correlation was therefore found between plankton density and $\mathrm{pH}$ in the Aftissat area (Fisher $=5.19, \mathrm{p}<0.048)$.

\subsubsection{Dissolved Oxygen}

The average annual rate of dissolved oxygen in sampling sites in the Afissat zone is $5.96 \pm 0.57 \mathrm{mg} / \mathrm{l}$, with a minimum of $5.20 \mathrm{mg} / \mathrm{l}$ and a maximum of $7.10 \mathrm{mg} / \mathrm{l}$. Fisher's test shows that month variation has a very highly significant effect on the monthly distribution of dissolved $\mathrm{O}_{2}$. However, the average comparison shows that October has the lowest average dissolved $\mathrm{O}_{2}(5.2 \mathrm{mg} / \mathrm{l})$ and August the highest average $(7.1 \mathrm{mg} / \mathrm{l})$, the mean dissolved $\mathrm{O}_{2}$ levels recorded in the samples corresponding to the three algal classes do not show a significant difference (fisher $=0.36, \mathrm{p}<0.71$ ). In addition, the species identified in samples where the dissolved $\mathrm{O}_{2}$ level is less than $5.8 \mathrm{mg} / \mathrm{l}$ are Ceratium furca (5.45); Stolterfothii (5.53); Asterionella sp. (5.63); Ostreopsis sp. (5.65); Lauderia spp. (5.718); Alexandrium spp. (5.75); Rhizosolenia sp. (5.75); Prorocentrum (5.78); Pseudo nitzschia spp. (5.79) and Tabellaria sp. (5.80). In contrast, the species listed in samples with high levels of dissolved $\mathrm{O}_{2}(>6.2 \mathrm{mg} / \mathrm{l})$ are Amphora (6.20); Guinardia sp. (6.20); Biddulphia spp. (6.25); Pleurosigma sp. (6.41) and Katodinium spp. (6.5).

The correlation between density and dissolved oxygen was significant in the Aftissat zone $(4.42, \mathrm{p}<0.05)$.

\subsubsection{Salinity}

It refers to the amount of salts dissolved in the water. The average annual content in the Aftissat zone is $36.37 \pm 0.21 \mathrm{mg} / \mathrm{l}$, with a minimum of $36 \mathrm{mg} / \mathrm{l}$ and a maximum of $36.7 \mathrm{mg} / \mathrm{l}$. Fisher's test shows that month variation has a very highly significant effect on the monthly distribution of salinity. On the other hand, the month of October has the lowest average rate of dissolved salt (36 $\mathrm{mg} / \mathrm{l})$ and the month of March has the highest average rate $(36.7 \mathrm{mg} / \mathrm{l})$. Species with the ability to be found in waters rich in dissolved salt are Surirella sp. (36.53); Ostreopsis sp. (36.5); Prorocentrum (36.49); Alexandrium spp. (36.48); Thalassiosira spp. (36.47); Lauderia spp. (36.47); Triceratium sp. (36.46).

The correlation between density and salinity is negative, this shows that the abundance of planktonic species is advantageous in low salinity environments, although this correlation is not significant $(\mathrm{r}=-0.45, \mathrm{p}<0.39)$. 


\subsubsection{Phosphate, Nitrite and Nitrate}

The annual average levels of phosphate, nitrite and nitrate in the Aftissat area are as follows: $0.29 \pm 0.07 ; 0.28 \pm 0.8$ and $0.22 \pm 0.13$ ( $\mu \mathrm{mol} / \mathrm{l})$. For phosphate, the minimum value is $0.10 \mu \mathrm{mol} / \mathrm{l}$ and the maximum level is $0.40 \mu \mathrm{mol} / \mathrm{l}$, while the average low content is recorded in December $(0.18 \mu \mathrm{mol} / \mathrm{l})$ and the highest content is marked in March $(0.40 \mu \mathrm{mol} / \mathrm{l})$. For nitrite and nitrate, the average monthly high levels are reported in July $(0.32 \mu \mathrm{mol} / \mathrm{l})$ and June $(0.23 \mu \mathrm{mol} / \mathrm{l})$, respectively.

\subsection{Joint Analysis}

Figure 3 presents the results of the physicochemical parameter projection in the space composed of axes 1 and 2 of the principal components analysis. The two axes alone absorb more than $60 \%$ of the total variation. Reading this graph show that the average temperature and salinity in the Afissat zone generally change inversely along axis 1 , as doe's $\mathrm{pH}$, and the phosphates move in opposite directions along axis 2 . On the other hand, we note that planktonic species abundance is governed by temperature, $\mathrm{pH}$ and dissolved oxygen parameters and conversely to salinity.

To draw conclusions about the behavior of planktonic species with respect to these physicochemical parameters studied, we superimposed the projections of parameters and species:

- The projection of the average points of all the species according to the two axes 1 and 2 (Figure 4), in compatibility with the projection of the physicochemical parameters, shows that some species tolerate medium high temperatures, but are sensitive to high levels of salinity like Pseudo nitzschia spp. (744), Navicula sp. (544.67) and Chaetoceros (500) and other amphora species...

- Conversely, some species show great adaptation to high levels of salinity but do not tolerate high temperatures such as Protoperidinium spp. (84), Cosciniducus, Odontella, Dictyocha (70), Biddulphia spp. (93.33)...

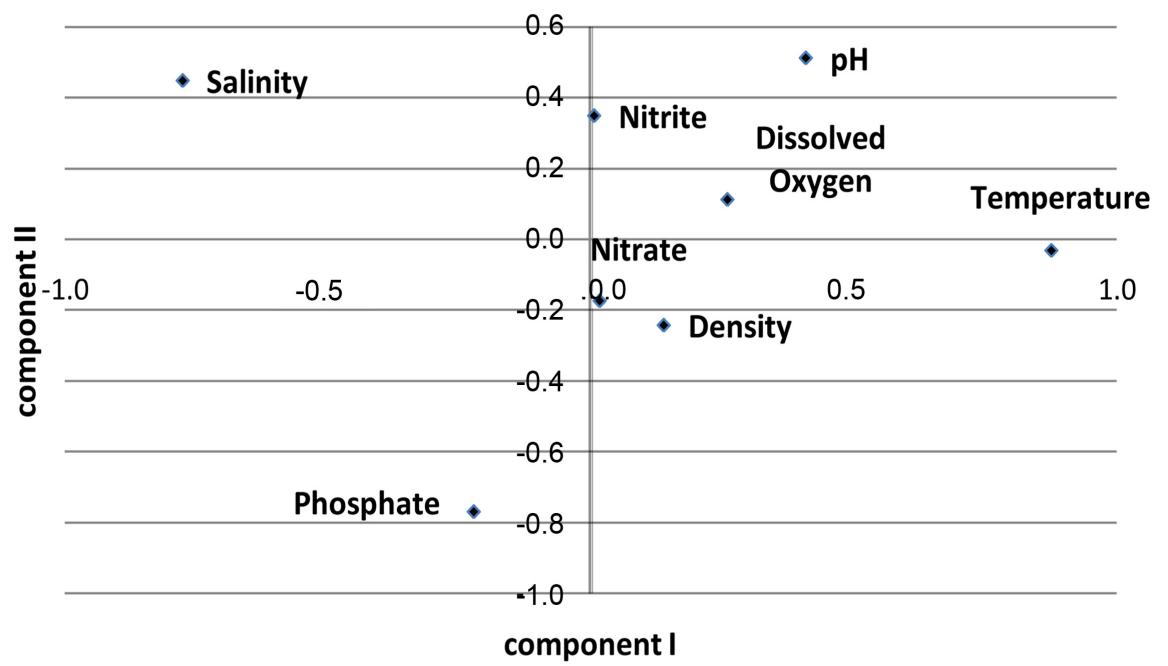

Figure 3. Projection of physicochemical parameters in ACP. 


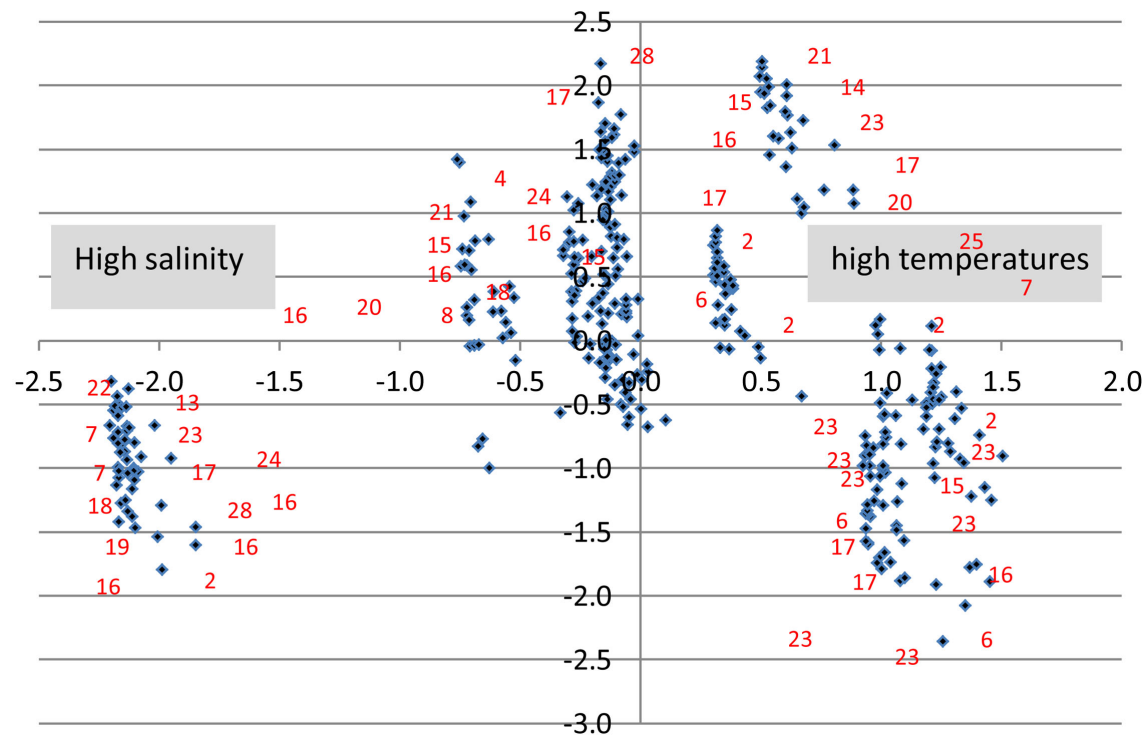

Figure 4. Projection of average points of planktonic species. 1: Alexandrium spp.; 2: Amphora; 3: Asterionella sp.; 4: Biddulphia spp.; 5: Ceratiumfurca; 6: Chaetoceros; 7: Coscinodiscus; 8: Dictyocha; 9: Dinophysis, 10: Diplonies sp.; 11: Guinardia sp.; 12: Katodinium spp.; 13: Lauderia spp.; 14: Leptocylindrus, 15: Licmophora; 16: Navicula sp.; 17: Nitzschia sp.; 18: Odontella spp.; 19: Ostreopsis sp.; 20: Pleurosigma sp.; 21: Prorocentrum; 22: Protoperidinium spp.; 23: Pseudo nitzschia spp.; 24: Rhizosolenia sp.; 25: Scrippsiella spp.; 26: Stolterfothii; 27: Surirella sp.; 28: Tabellaria sp.; 29: Thalassiosira spp. and Triceratium sp.

\section{Discussion}

The study we conducted in cape Aftissat, known by massive phytoplankton blooms, consists of the determination of the planktonic species community and the physicochemical characteristics of the cape. This geographical area is characterized by eutrophication [3].

The results of the species identification show that 30 phytoplankton species have been recorded, of which $70 \%(n=21)$ are diatoms, $26.67 \%$ are dinoflagellates and a single species of the class silicoflagellates. Our results are consistent with those found in the work done in Megagine Lake in Algeria by Taleb and Noui (2011) [11] and Benfiala et al. (2013) [12]. In a study conducted by Nadège ROSSI (2008) [13], in the Grande Rade, Bacillariophyceae were also the group best represented with 60 species followed by Dinophyceae (55).

Phytoplankton evolves seasonally both in the lake environment [14] and in the marine environment [15]. The highest densities are recorded during the summer and spring season. Indeed, during the spring and summer seasons, the sun heats the surface water, which makes them less dense. This warm water floats above colder and denser waters, which is normal. This implies that the phytoplankton that develops stays on the surface. It contains abundant light and nutrients, as nutrients are brought up from deep waters during the winter [16]. However, during the fall and winter seasons, the days get shorter and the sun warms less the water. Surface waters cool and their density increases. This makes 
the amount of nutrients a bit low and this affects plankton abundance. Nevertheless, the most abundant species in the diatoms are Navicula sp. (69), Licmophora (47), Nitzschia sp. (35), Pseudo nitzschia spp. (31) and in the class Dinoflagellates, Scrippsiella spp. (24), Protoperidinium spp. (11).

The physicochemical parameters (temperature, salinity, $\mathrm{pH}$, dissolved oxygen, nitrate and nitrite and phosphate) play an important role in the proliferation of phytoplankton; a significant correlation $(\mathrm{p}<0.05)$ was shown between these parameters and the density. Thus, cape Boujdour is a Saharan zone where the dust brought by the wind is too abundant. These dusts provide a significant amount of dissolved inorganic phosphorus, a nutrient essential for development [17].

\section{Conflicts of Interest}

The authors declare no conflicts of interest regarding the publication of this paper.

\section{References}

[1] Gleick, P.H. (1993) Water Resources: A Long-Range Global Evaluation. Ecology Law Quarterly, 20, 141-149.

[2] Costanza, R., Arge, R., de Groot, R., Stephen, F.K., Monica, G., Bruce, H., Karin, L., Shahid, N.R., O’Neill, V., Jose, P., Robert, G.R., Paul, S.K.K. and van den Marjan, B. (1997) The Value of the World's Ecosystem Services and Natural Capital. Nature, 387, 253-260. https://doi.org/10.1038/387253a0

[3] Ferreira, J.G., Andersen, J.H., Borja, A., Bricker, S.B., Camp, J., Da Silva, M.C., Garcés, E., Heiskanen, A.S., Humborg, C., Ignatiades, L., Lancelot, C., Menesguen, A., Tett, P., Hoepffner, N. and Claussen, U. (2011) Overview of Eutrophication Indicators to Assess Environmental Status within the European Marine Strategy Framework Directive. Estuarine, Coastal and Shelf Science, 93, 117-131. https://doi.org/10.1016/j.ecss.2011.03.014

[4] Vazquez, G. and Favila, M.E. (1998) Status of the Health Conditions of Subtropical Atezea Lake. Aquatic Ecosystem Health and Management, 1, 245-255. https://doi.org/10.1016/S1463-4988(98)00017-7

[5] Dokulil, M., Chen, W. and Cai, Q. (2000) Anthropogenic Impacts to Large Lakes in China: The Tai Hu Example. Aquatic Ecosystem Health and Management, 3, 81-94. https://doi.org/10.1016/S1463-4988(99)00067-6

[6] Tazi, O., Fahde, A. and El Younoussi, S. (2001) Impact de la pollution sur l'unique réseau hydrographique de Casablanca, Maroc. Sécheresse, 12, 129-134.

[7] Silva, T., Lemaire, B.J. and Vinçon-Leite, B. (2011) Monitoring of Phytoplankton in Urban Lakes Using an Instrumental Buoy: The Casdulac of Enghien-les-Bains; Paris-Est University, Champs-sur-Marne, 2.

[8] le Grand, G. (1978) Dialogues. Volume I. Introduction, Bibliography and Maps by Adalbert de Vogué.

[9] Bourrelly, P. (1985) Blue and Red Algae. Euglenes, Peridinians and Cryptomonadales. Freshwater Algae, Tome 3. Boubée Ed \& Cie, Paris, 606 p.

[10] Aminot, A. and Kérouel, R. (2004) Hydrologie des écosystèmes marins: Paramètres et analyses, Ifremer.

[11] Noui, M. and Taleb, R. (2011) Physico-Chemical Characteristic and Trophic Level 
of a Brackish Water Body (Méggarine Lake).

[12] Benfiala, Z., Mefatih, H. and Rouighi, Z. (2013) Contribution to the Determination of the Phytoplankton Community Inhabiting Méggarine Lake (Touggourt) License Thesis.

[13] Rossi, N. (2008) Ecology of Mediterranean Plankton Communities and Study of Heavy Metals (Copper, Lead, Cadmium) in Different Compartments of Two Coastal Ecosystems (Toulon, France). Ecology, Environment. University of South Toulon Var, La Garde.

[14] Amblard, M. (1998) The Theory of Conventions: A Renewed Approach to the Accounting Model. Proceedings of the XIXth Congress of the AFC, Tome II, 1017-1030.

[15] Margalef, R. (1958) Information Theory in Ecology. General Systems, 3, 36-71.

[16] Skulberg, O.M., Carmichael, W. and Cood, G.A. (1984) Toxic Blue-Green Algal Blooms in Europe: A Growing Problem. AMBIO A Journal of the Human Environment, 13, 244-247.

[17] Loÿe-Pilot, M.D., Klein, C. and Martin, J.M. (1993) Major Inorganic Elements in North Western Mediterranean Aerosols. Concentrations and Sources; Estimation of Dry Deposition of Soluble Inorganic Nitrogen. EROS 2000 (European River Ocean System) Project Fourth Workshop. In: Martin, J.M. and Barth, H., Eds., Water Pollution Research Report, CEC, Brussels, 271-277. 